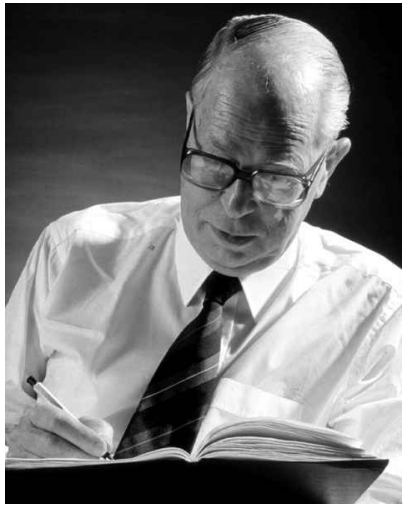

\section{In memory of Arvid Wretlind 1919-2002}

Arvid Wretlind was born in Avesta, Sweden, in 1919. He studied medicine at the Karolinska Institute in Stockholm and in 1949 he defended his thesis on "The effect of synthetic amino acids essential for growth on the body weight of growing rats, and the synthesis of the amino acids used". During the period 1949-1962 he was Assistant Professor in Pharmacology at the Karolinska Institute. His most important basic research in developing safe parenteral nutrition solutions was performed during these years. In 1962 he became responsible for food and nutrition within the Swedish National Institute for Public Health, an appointment he held until 1970.

In 1968 Arvid Wretlind started courses in nutrition at the University of Stockholm and the Karolinska Institute, where he was Assistant Professor and from 1975 to 1977 Professor of General Nutrition. In the time that followed he continued the earlier very successful research into parenteral nutrition. From 1977 to 1979 he was Head of the Vitrum Institute for Human Nutrition, and from 1979 to 1990 Director of the Cutter-Vitrum Institute for Human Nutrition at the University of California, Berkeley, USA. Wretlind was Scientific Adviser to the Swedish National Board of Health and Welfare from 1968 and a member of the Royal Swedish Academy of Engineering Sciences.

Arvid Wretlind worked intensely to develop upto-date food legislation, resulting in a new food law in 1972 and the establishment of the Swedish National Food Administration. He was also President of the non-governmental organization Vår Näring, an important organization for providing education about food and nutrition in primary schools.

As Wretlind's pioneering work in parenteral nutrition illustrates the collaboration between clinical and preclinical research, it is of general interest to know how it started. Clarence Crafoord, a well- known thoracic surgeon in Stockholm, Sweden, initiated Arvid Wretlind's interest in parenteral nutrition. During his visit to the USA at the end of World War II, Crafoord studied surgery in war. He was impressed by the intravenous nutritional support given to patients who could not eat. By this method patients were not undernourished, and lifethreatening complications after surgery could be avoided. The intravenous solutions were, however, not ideal. In particular, the fat emulsion, Lipomul, had side-effects and was consequently withdrawn from the market. Crafoord understood the importance of developing a safe emulsion for parenteral nutrition. He communicated with Professor Erik Jorpes at the Department of Medical Chemistry, Karolinska Institute, who suggested the young research fellow Arvid Wretlind to start working on the problem of preparing a solution of amino acids and later fat, suitable for intravenous infusion. At the end of the 1940s, Wretlind, in collaboration with Ivan Håkansson, developed an amino acid preparation, an enzymatic hydrolysate of casein, dialysed from non-hydrolysed peptides. The solution Aminosol was born, and was used successfully until the mid-1980s. In 1954 Arvid Wretlind began to work with fat emulsions for intravenous use in human patients. In the USA at that time a lot of money was invested in research at the US Army Nutritional Laboratory, but they did not succeed in preparing a non-toxic emulsion. However, after several years Wretlind succeeded in producing a fat emulsion, named Intralipid, which was introduced for clinical use in 1962. The research behind Intralipid is certainly Arvid Wretlind's most important contribution. After 40 years Intralipid is still the most used fat emulsion world-wide and is given to millions of patients. Intralipid is produced from soyabean oil, emulsified by phospholipids from egg, which stabilize the emulsion.

At a Vitrum symposium in Kungälv in 1962, Arvid Wretlind together with his co-worker and surgeon Oscar Schuberth presented for the first time a programme for complete intravenous nutrition, named the Scandinavian model. This programme was seminal in the development of better treatment in surgery and intensive care. Wretlind stated that the success of Intralipid was due to his discovery that the dog was such a perfect laboratory animal, being extremely sensitive to intravenous emulsions. Thanks to Arvid Wretlind, 
Sweden became world leader in intravenous nutrition for the rest of the twentieth century. He also developed other nutritional solutions containing vitamins and minerals. With good reason Arvid Wretlind can be called the father of parenteral nutrition.

Arvid Wretlind also had a central role in the development of research and education in nutrition in Sweden. Together with Professor Gunnar Blix at the University of Uppsala and the Swedish Nutrition Foundation, he was engaged in the debate on the development of Swedish dietary and food habits after World War II, and their influence on public health.

His classic work, presented together with Blix, Bergström and SI Westin, "The Swedish food habits" (Den svenska folkkosten), was the basis for the first Swedish dietary guidelines. He initiated the Swedish National Board of Health and Welfare in 1969 to start the campaign "Diet and physical activity" (Kost och Motion), and he was the first chairman of its medical expert group, MEK for adults and MEK-B for children. The basic principle was to pool the recommendations of changed dietary habits and advice on physical activity, which at that time was unique in both a national and international perspective. In that way it was possible to engage sports associations in the campaign.

The Food circle "Kost cirkeln", introduced in the 1960s, is an example of Wretlind's interest in developing simple tools to provide information on forming better eating habits. He encouraged co-operation between national authorities and the food sector to create food habits for improving public health. He initiated the expert group for the Coordination of Hospital Diets (1963).

Arvid Wretlind took the initiative to elaborate the Nordic Nutrition Recommendations, together with colleagues from the other Nordic countries. He was a prominent figure in the development of nutrition in medical research and basic education in Sweden. He established early contact with the Swedish Society of Medicine to start a section of nutrition within the society, with the aim of obtaining support for the recommendations from the medical profession.

He was also instrumental in the creation of a professorship in nutrition at our medical faculties. The first academic education programme in nutrition was logically created in a joint programme between Stockholm University and the Karolinska Institute.

Arvid Wretlind belonged to the first generation of professors in nutrition. His basic research in parenteral nutrition was outstanding, and his practical applications, both in parenteral nutrition and in applied nutrition for better public health, were of great importance for the development of nutrition research.

We, who have had the privilege to become acquainted with Arvid Wretlind as a colleague and as a friend, deeply regret this loss and feel great gratitude for his contribution to Swedish nutrition research.

Björn Isaksson, Leif Hambraeus, Erik Vinnars, Gösta Samuelson, Jörgen Larsson and Nils-Georg Asp 